\title{
MEMBANGUN BODY IMAGE MELALUI ACCEPTANCE AND COMMITMENT THERAPY (ACT) PADA PASIEN KANKER PAYUDARA
}

\author{
Ria Rizki Utami ${ }^{1}$ \\ Iswinarti \\ Djudiyah \\ Magister Psikologi Profesi, \\ Pascasarjana Universitas Muhammadiyah Malang
}

\begin{abstract}
Post-treatment for cancer patients have an impact on psychological discomfort, changes in lifestyle, fear and anxiety. One effect that often arises in breast cancer patients is a negative assessment of post-masectomy appearance such as breast removal. Development of body image problems related to low self acceptance in cancer patients. Interventions used to build a positive body image through acceptance and commitment therapy (ACT) in breast cancer patients. The design of study used a pretest-post-test control group design and the subjects involved in this study were breast cancer patients who were undergoing treatment at the age range of 30-50 years and had low score on body image scale. The data analysis method uses non-parametric analysis (Wilcoxon and Mann Whitney test) with SPSS. The results showed that ACT had an influence on body image in breast cancer patients. That is, ACT is able to build a positive body image in breast cancer patients.
\end{abstract}

Keywords: acceptance and commitment (ACT), body image, breast cancer

\begin{abstract}
ABSTRAK: : Operasi pada pasien kanker payudara berdampak pada ketidaknyamanan psikologis, perubahan pada pola hidup dan ketakutan serta kekhawatiran terutama ialah penilaian negatif terhadap penampilan (body image) pasca masektomi (pengangkatan payudara). Permasalahan pada penampilan pasien kanker payudara berdampak pada penolakan untuk perawatan lanjutan. Intervensi yang digunakan untuk membangun body image yang positif adalah acceptance and commitment therapy (ACT). Desain penelitian ini menggunakan pretest-post-test control group design, melibatkan 12 pasien kanker payudara yang sedang menjalani perawatan dengan rentang usia 30-50 tahun, dan memiliki skor rendah pada body image scale. Penelitian ini menggunakan analisis non parametrik (uji wilcoxon dan mann whitney) dengan SPSS. Hasil penelitian menunjukkan bahwa ACT memiliki pengaruh terhadap body image dan meningkatkan penerimaan diri pada pasien kanker payudara. Artinya, ACT mampu membangun body image positif dan meningkatkan penerimaan diri pada pasien kanker payudara.
\end{abstract}

Kata kunci: acceptance and commitment (ACT), body image, kanker payudara.

\footnotetext{
${ }^{1}$ Korespondesni mengenai isi artikel ini dapat dilakukan melalui: Ririzky5@gmail.com
} 
Kanker payudara merupakan penyebab paling umum kematian pada wanita. Kanker payudara merupakan penyakit yang memiliki tingkat insiden kejadian dan kematian tertinggi di antara semua kanker pada wanita, baik di negara maju dan berkembang (Chen, Zheng, Baade, Zhang, \& Zeng, 2016). Di Indonesia angka kejadian wanita pengidap penyakit kanker payudara dengan persentase 42,1 per 100.000 penduduk dengan rata-rata kematian 17 per 100.000 penduduk (Kemkes.go.id., 2019).

Kanker payudara memiliki waktu kambuh yang berbeda secara signifikan dengan kanker lainnya. Perbedaan waktu kambuh ini menjadi asumsi untuk menentukan kelangsungan hidup pasien kanker payudara. Sebagian besar penelitian telah menjelaskan bahwa faktor psikososial menentukan hasil evaluasi klinis kanker payudara. Penelitian-penelitian tersebut menyebutkan bahwa depresi, kecemasan, buruknya citra diri, serta koping yang tak sehat (Malik \& Kiran, 2013); distress akibat penyakit dan ketidakpastian, kekhawatiran dan ancaman masa depan (Al-Azri, Al-Awisi, Al-Rasbi, El-Shafie, Al-Hinai, Al-Habsi \& AlMoundhry, 2014); gelisah, kesedihan, keputusasaan atau tidak berdaya, kelelahan, gangguan konsentrasi, gangguan tidur, reservasi mental dan kognitif, gangguan seksual, serta gangguan kejiwaan (Izci, Ilgun, Findikli \& Ozmen, 2016) merupakan masalah psikologis yang dialami pasien kanker payudara.

Beberapa gejala tekanan psikologis pun muncul, seperti kecemasan, depresi, kelelahan, nyeri kronis, sulit berkonsentrasi, isolasi sosial, masalah seksualitas, serta menyalahkan diri sendiri sehingga mengakibatkan kualitas hidup menurun. Namun, ada pula pasien kanker payudara yang menggunakan beberapa strategi untuk menerima diagnosis, sehingga ia mampu mendefinisikan kembali sesuai dengan kapasitas dirinya. Beberapa strategi penanganan atau koping yang digunakan untuk meningkatkan penerimaan terhadap diagnosis tersebut ialah restrukturisasi kognitif, yoga, dan meningkatkan religiusitas (Al-Azri, Al-Awisi, Al-Rasbi, \& Al-Moundhri, 2013; Al-Azri et al., 2014).

Dampak psikososial dari kanker payudara meliputi tiga komponen yaitu: ketidaknyamanan psikologis (kecemasan, depresi, dan kemarahan), dan perubahan pola hidup (ketidaknyamanan fisik atau cacat, gangguan dalam pernikahan, dan tingkat aktivitas yang berubah), serta ketakutan dan kekhawatiran (terkait dengan efek masektomi, kekambuhan penyakit, ketidakpastian tentang masa depan, kemungkinan kematian, dan masalah eksistensial). Wanita dengan kanker payudara dituntut untuk mampu menerima semua efek psikososial dari penyakit yang diderita (Chen, Liu, Zhang, \& Li, 2017).

Terdiagnosis kanker payudara menjadi pemicu reaksi buruk pada sebagian besar wanita. Tidak hanya masalah fisik melainkan permasalahan psikologis yang harus dihadapi. Wanita kerap kali menghadapi masalah body image. Kekhawatiran body image atau citra tubuh pada wanita dikaitkan dengan hilangnya payudara pasca operasi, bekas luka dan perubahan fisik lainnya, berdampak pada kualitas hidup secara keseluruhan, khususnya pada persepsi tubuhnya (Rosenberg et al., 2013).

Beberapa penelitian terdahulu menyebutkan bahwa prevalensi permasalahan body image pada pasien kanker mencapai $30 \%$ yang berdampak pada terhambatnya proses pengobatan. Selain itu, kekawatiran ini secara signifikan berkorelasi dengan tingkat kecemasan, kualitas hidup yang memburuk dan depresi yang lebih tinggi pada pasien kanker. Body image berkorelasi secara langsung dengan rendahnya kepercayaan diri, fungsi seksual, hubungan sosial yang buruk dan depresi (Izci, Ilgun, Findikli \& Ozmen, 2016). Pada 
pasien kanker, perubahan fisik, mental dan sosial merupakan hal yang penting untuk bertahan dan kembali menikmati kehidupan. Pada individu dengan penyakit kronis memiliki peluang yang lebih besar mengalami permasalahan body image. Masalah pada kesehatan fisik dapat berdampak pada persepsi diri tentang tubuhnya (Przezdziecki et al., 2013; Jansen, et al., 2016). Selain itu, dampak dari body image negatif pada pasien kanker payudara adalah menghadapi dirinya sendiri pasca perawatan. Payudara diangkat, perubahan pada elatisitas kulit, berat badan naik atau turun signifikan, dan penolakan terhadap penampilannya. Kekhawatiran juga timbul pada penerimaan pasangan penderita kanker yaitu ketakutan tidak diterima kembali apabila penampilannya tidak menarik lagi dan juga kualitas hubungan romantis akan bermasalah (Przezdziecki et al., 2013).

Body image merupakan konstruksi
yang melibatkan pikiran, perasaan
mengenai seluruh tubuh dan fungsinya
(Bohon, Stice, \& Burton, 2010; Allen, Byrne,
\& Crosby, 2015; Tylka, \& Wood-Barcalow, 2015). Body image menjadi problem psikososial yang penting bagi pasien kanker (Bates, 2016). Body image menjadi faktor penting dalam menentukan keputusan melakukan perawatan lanjutan pada pasien kanker. Individu dengan body image positif akan lebih mudah menerima, memahami dan mencintai tubuhnya (Wood-Barcalow, Tylka, \& Augustus-horvath, 2010). Konseptualisasi body image yang baik pada wanita disinyalir mampu mengatasi dan menghadapi kanker dengan lebih baik. Persepsi tubuh yang buruk memiliki potensi negatif pada fungsi fisik dan psikologis pada pasien kanker payudara serta kesejahteraan pasangan. Body image negatif dikaitkan dengan tekanan psikologis yang lebih besar pada pasien kanker payudara seperti distress di awal diagnosis (Liu, Xu, \& Mahendran, 2017; Przezdziecki, 2013) dan kemungkinan depresi (Han, Grothuesmann, Neises, Hille, \& Hillemanns, 2010). Penerimaan yang baik dapat membuat penderita kanker berdamai dengan dirinya, sehingga mampu mengurangi distress yang dialami.

Bukti empiris menunjukkan penerimaan diri secara positif berkaitan dengan subjective well-being. Ryff menegaskan bahwa penerimaan diri merupakan bentuk evaluasi diri yang berhubungan kuat dengan self esteem (Bernard, 2013; Pop, 2016). Individu dengan penerimaan diri rendah kerap kali ditemukan memiliki self esteem dan subjective well-being yang rendah. Dapat disimpulkan bahwa individu dengan penerimaan diri tinggi, mampu menyesuaikan kondisi emosional dengan realitas yang harus dihadapi, dan memiliki keyakinan pada kemampuan dan kapasitas diri, memandang diri berharga, bertanggung jawab, serta mampu menerima kekurangan dan kelebihan.

Meskipun penelitian-penelitian yang ada menganggap bahwa penerimaan diri itu penting bagi pasien, namun mayoritas intervensi yang diberikan banyak yang fokus pada teknik relaksasi atau penurunan kecemasan, problem solving, psikoedukasi, serta cognitive-behavioral strategies. Terapi cognitive-behavioral therapy (CBT) jenis baru, yaitu acceptance and comitment therapy (ACT) lebih memfokuskan penerimaan sebagai fokus utama dan terbukti efektif dalam intervensi terhadap pasien kanker (Najvani, Neshatdoost, Abedi, \& Mokarian, 2015). Acceptance and comitment therapy (ACT), merupakan terapi penerimaan diri yang berkontribusi pada pengembangan fleksibilitas psikologis, melibatkan kesadaran penuh akan peristiwa saat ini dan melakukan tindakan yang selaras dengan nilai-nilai pribadi (Hulbert, Storey, \& Wilson, 2015). Acceptance and comitment therapy adalah pendekatan cognitive behavior generasi ketiga yang bertujuan untuk mengembangkan 
fleksibilitas psikologis. Intervensi ini bertujuan untuk meningkatkan aspek psikologis untuk lebih fleksibel dalam menjalani perubahan yang terjadi saat ini dengan lebih baik (Fischer \& Fink, 2014; Najvani, Neshatdoost, Abedi, \& Mokarian, 2015; Hulbert, Storey, \& Wilson, 2015). Berbeda dengan teori perubahan perilaku sebelumnya, ACT mempengaruhi hubungan individu dengan kognisi namun tidak secara langsung mengubah untuk mengontrol perilaku melainkan lebih menekankan pada sikap positif dalam menerima peristiwa saat ini.

Penerimaan diri membantu individu mencapai kesadaran dan komitmen, mendukung proses perubahan perilaku. Kedua keterampilan ini adalah inti dari ACT, sehingga individu mampu menghadapi situasi saat ini dan menyikapi sesuai dengan nilai (Han, Liu, Su, \& Qiu, 2019; Hayes et al., 2012). Pada pasien kanker, nilai-nilai ini digunakan sebagai arah menentukan hidup yang ditentukan secara personal sehingga dapat memberikan makna dan tujuan (Feros, Lane, Ciarrochi, \& Blackledge, 2011; Secinti, Tometich, Johns, \& Mosher, 2019). Penelitian yang dilakukan Hayes, Strosahl, dan Wilson (2012) menunjukkan bahwa penerimaan pada pasien kanker menunjukkan berkurangnya tekanan, khususnya pada kanker, depresi, kecemasan, dan permasalahan psikologis lainnya.

Intervensi dengan menggunakan ACT menunjukkan efek yang signifikan untuk mengatasi distres, meningkatkan kualitas hidup dan perilaku sehat pada pasien kanker payudara (Karekla \& Constantinou, 2010; Montesinos, Luciano, Almería, \& Act, 2016). Selain itu, ditemukan pula pada pasien tumor otak, dan pada populasi kanker lainnya (Cederberg \& Dahl, 2017; Kangas, Mcdonald, Williams, \& Smee, 2015). ACT mampu mengatasi ganguan mood, ketakutan berlebihan pada kekambuhan kanker, trauma, dan meningkatkan flesibilitas psikologis (Arch \& Mitchell, 2016; Datta, Aditya, Chakraborty, \& Das, 2015).

Penelitian body image sebelumnya lebih berfokus pada gangguan makan pada remaja perempuan dan dewasa awal (Rudiger, \& Winstead, 2013). Masih sedikit literatur yang membahas perempuan yang mengalami masalah body image dengan keterbatasan fisik atau sakit fisik (Cash \& Smolak, 2011). Secara umum, model intervensi yang sering digunakan untuk mengatasi individu dengan permasalahan body image dengan indikasi gangguan makan adalah menggunakan dasar terapi dengan cognitive behavioral therapy (CBT) (Marco, Perpiñá, \& Botella, 2013). Penelitian terbaru menyebutkan bahwa ACT secara signifikan meningkatkan fleksibilitas dan kesadaran diri terhadap body image pada pasien dengan gangguan psikosomatik dan tulang belakang (Bailey, Gammage, Ingen, \& Ditor, 2015; Givehki et al., 2018). Pada masalah yang terkait dengan citra tubuh, ACT terbukti cukup efektif, seperti pada penelitian yang dilakukan oleh Pearson, Follette, dan Hayes (2012). ACT mampu menurunkan tingkat kecemasan terkait dengan tubuh dan meningkatkan penerimaan terhadap tubuh. Hal tersebut juga didukung oleh penelitian yang dilakukan Rafiee, Sedrpoushan, dan Abedi (2014) yang membuktikan bahwa ACT efektif untuk meredakan kecemasan dan menurunkan tingkat ketidakpuasan tubuh pada wanita yang mengalami obesitas. Akan tetapi, teknik intervensi ini masih dikatakan baru dan perlu diuji ulang dengan subjek yang berbeda.

Berdasarkan bebeberapa literatur di atas peneliti berasumsi bahwa ACT mampu membangun body image positif pada pasien kanker payudara. Disebutkan pada penelitian sebelumnya bahwa ACT telah dilakukan pada pasien gangguan psikosomatik, gangguan pada tulang belakang dan pada gangguan makan yang memiliki permasalahan terhadap body 
image. Penelitian ini bertujuan untuk mengetahui pengaruh acceptance and comitment therapy terhadap body image pada pasien kanker payudara. Diharapkan penelitian ini dapat memberikan sumbangan dalam perkembangan ilmu dan praktik dalam bidang psikologi klinis. Selain itu, ACT dapat dijadikan salah satu terapi untuk membangun body image positif pada pasien kanker lainnya.
Acceptance and comitment Therapy

$(A C T)$

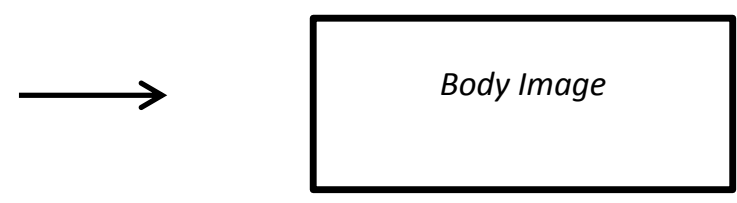

Gambar 1. Kerangka Berpikir

\section{METODE PENELITIAN}

\section{Desain Penelitian}

Penelitian ini menggunakan kuasi eksperimen. Desain penelitian yang digunakan adalah control group pre-testposttest design. Subjek penelitian ditentukan dengan menggunakan nonrandom sampling dengan kriteria yang telah ditentukan peneliti dan atas rekomendasi dokter penyakit dalam yang mensupervisi. Sampel penelitian kemudian diberi pretest untuk mengetahui keadaan awal kelompok eksperimen dan kelompok kontrol. Setelah diberi manipulasi, dilakukan pengukuran kembali terhadap variabel terikat dengan alat ukur yang sama pada dua kelompok dengan dua situasi yang berbeda (Creswell, 2010).

\section{Subjek Penelitian}

Subjek dalam penelitian ini melibatkan 12 orang pasien kanker payudara, dengan karakteristik sebagai berikut: 1) telah didiagnosis kanker payudara, 2) sedang menjalani perawatan kemoterapi atau radioterapi, 3) pasca masektomi atau pengangkatan payudara, 4) berusia 24-50 tahun, 5) sudah menikah. Subjek dibagi menjadi dua kelompok yaitu kelompok kontrol dan kelompok eksperimen, yang masing-masing terdiri dari enam (6) orang.

\section{Metode Pengumpulan Data}

Variabel terikat dalam penelitian ini adalah body image. Body image merupakan penilaian subjektif terhadap penampilan diri yang meliputi pikiran dan perasaan. Instrumen penelitian menggunakan body image scale (BIS) (Hopwood, Fletcher, Lee, \& Ghazal, 2001) untuk pasien kanker payudara. Skala BIS ini berjumlah total 10 item yang meliputi tiga aspek yaitu kognitif, afektif, dan perilaku, di mana masing-masing aitem memiliki 4 pilihan jawaban (1=sangat tidak setuju hingga $4=$ sangat setuju) dengan nilai reliabilitas sebesar 0,834 .

\section{Prosedur Intervensi}

Penelitian ini dilakukan melalui tiga tahapan, di antaranya sebagai berikut:

Tahap persiapan. Pada tahap ini peneliti mulai mendalami materi dan melakukan uji coba pada instrumen penelitian dan modul. Tujuan uji coba instrumen adalah untuk menguji kelayakan instrumen setelah diadaptasi dan diterjemahkan ulang, sehingga mampu mengukur variabel penelitian secara valid dan reliabel. Uji coba modul bertujuan untuk melihat efektivitas isi modul dalam membantu subjek dalam membangun body image positif. Selanjutnya, peneliti memilih subjek yang sesuai dengan kriteria penelitian, dan diperoleh 12 subjek. Semua subjek kemudian diberikan skala pra tes untuk melihat skor body image masing- 
masing subjek. Berdasarkan hasil skor pra tes tersebut, peneliti membagi menjadi dua kelompok, yaitu kelompok kontrol dan eksperimen.

Tahap intervensi. Intervensi yang dilakukan pada penelitian ini yaitu acceptance and commitment therapy. Sebelum melakukan serangkaian kegiatan, peneliti melakukan pengukuran body image pada partisipan untuk mengetahui kategori pada partisipan yaitu positif atau negatif. Tahap intervensi dilakukan sebanyak 7 sesi dalam jangka waktu 3 minggu, dengan durasi selama 60-120 menit. Adapun sesisesi terapi adalah sebagai berikut: 1) membangun kerjasama dan kontrak penelitian; 2) memahami kondisi diri; 3) difusi kognitif; 4) accepting and maindfulning; 5) commitment; 6) menemukan niali-nilai positif diri, 7) evaluasi dan terminasi. Secara rinci penjelasan prosedur terdapat pada modul penelitian.

Pasca intervensi, yaitu proses terakhir untuk menutup seluruh kegiatan intervensi yang dilakukan dan memberikan paska test. Proses terakhir yaitu tahap tindak lanjut, yang bertujuan meninjau kemajuan pada subjek paska intevensi yang sudah dilakukan.

\section{Teknik Analisis Data}

Data yang didapatkan dari penelitian dianalisa dengan menggunakan uji Mann Whitney dan uji wilcoxon untuk melihat perbedaan, peningkatan dan pengaruh manipulasi yang diberikan. Analisa dilakukan dengan membandingkan kondisi sebelum dan setelah terapi diberikan. Analisa statistik yang digunakan dalam penelitian ini adalah statistik nonparametrik. Hasil analisa hipotesis penelitian diuji menggunakan uji MannWhitney dan wilcoxon pada variabel body image. (Corder \& Foreman, 2014).

\section{HASIL DAN PEMBAHASAN}

\section{Deskripsi Data penelitian}

Penelitian ini dilakukan di Rumah Sakit Baptis, Batu, Jawa timur pada bulan November hingga Desember. Asesmen awal dilakukan pada pasien kanker payudara yang berada dalam daftar pasien paliatif untuk mencari informasi mengenai pengalaman selama didiagnosis kanker hingga perawatan yang dilakukan. Screening awal dilakukan kepada 15 pasien kanker payudara yang kemudian mengisi skala body image scale (BIS). Setelah itu, dilakukan skoring skala dan dilanjutkan dengan wawancara terhadap pasien untuk mengindentifikasi body image negatif. Hasil proses screening diperoleh 12 pasien pasien kanker payudara di rentang usia 24-50 tahun yang sesuai dengan kriteria penelitian. Seluruh subjek kemudian dibagi menjadi dua kelompok yaitu kelompok eksperimen dan kelompok kontrol yang masing-masing berjumlah 6 subjek.

Penelitian ini dilakukan selama 4 minggu dengan 8 kali pertemuan, dan sebanyak 7 sesi terapi. Adapun karakteristik subjek penelitian dapat dilihat pada tabel 1 . 
Tabel 1. Karakteristik Partisipan Penelitian

\begin{tabular}{llc}
\hline Karakteristik Demografis & \multicolumn{2}{c}{ Kelompok } \\
\cline { 2 - 3 } $\begin{array}{lll}\text { Jenis kelamin: } \\
\text { Perempuan }\end{array}$ Diagnosis & $6(100 \%)$ & Kontrol (N=6) \\
Kanker payudara & $6(100 \%)$ & $6(100 \%)$ \\
Menjalani perawatan & $4(67,7 \%)$ & $6(100 \%)$ \\
Kemoterapi & $2(33,3 \%)$ & $3(50 \%)$ \\
Radioterapi & $1(10 \%)$ & $3(50 \%)$ \\
Usia: & $5(90 \%)$ & $1(10 \%)$ \\
$24-38$ tahun & $6(100 \%)$ & $5(90 \%)$ \\
$39-50$ tahun & $0(0 \%)$ & $6(100 \%)$ \\
Status Pernikahan: & Menikah & $0(0 \%)$ \\
Belum menikah & &
\end{tabular}

\section{Uji Hipotesis}

Uji hipotesis menggunakan uji Wlicoxon untuk mengukur signifikansi perbedaan nilai sebelum dan sesudah pemberian perlakuan kepada kelompok eksperimen dan kelompok kontrol. Hasil pengujian sebelum dan sesudah pemberian perlakuan menggunakan instrumen BIS, dapat dilihat pada tabel 2 .

Tabel 2. Hasil Perbedaan sebelum dan sesudah tes Body image

\begin{tabular}{llllll}
\hline \multirow{2}{*}{ Variabel } & \multirow{2}{*}{ Jumlah Subjek (N) } & \multicolumn{2}{c}{ Mean } & \multirow{2}{*}{ Z } & \multirow{2}{*}{ Sig. (p) } \\
\cline { 3 - 5 } Eksperimen & 6 & Pretest & Posttest & & \multirow{2}{*}{0,027} \\
\hline Kontrol & 6 & 23,17 & 38,00 & $-2,207$ & 0,027 \\
\hline
\end{tabular}

Hasil uji pada tabel 2 menunjukkan, terdapat perbedaan nilai signifikasi body image dari hasil skor sebelum dan sesudah tes pada masing-masing kelompok. Kelompok eksperimen menunjukkan nilai $\mathrm{Z}=-2,207$ dengan $\mathrm{p}=0,027 \quad(\mathrm{p}<0.05)$. Artinya, terdapat perbedaan skor peningkatan body image secara signifikan pada kelompok eksperimen berdasarkan hasil prates dan pascates. Hal ini menunjukkan adanya pengaruh terbentuknya body image positif melalui ACT pada kelompok eksperimen. Pada kelompok kontrol diperoleh nilai $\mathrm{Z}=-0,632$ dan $\mathrm{p}=0.527(\mathrm{p}>0.05)$ yang artinya tidak terdapat perbedaan pada hasil prates dan pascates.

Tabel 3. Hasil perbandingan pengaruh Antar Kelompok Eksperimen dan Kelompok kontrol

\begin{tabular}{cccccc}
\hline \multirow{2}{*}{$\mathbf{N}$} & \multicolumn{2}{c}{ Mean } & $\mathbf{U}$ & $\mathbf{Z}$ & \multirow{2}{*}{} \\
\cline { 2 - 4 } & Kontrol & Eksperimen & & $-2,892$ & 0,004 \\
\hline 12 & 3,50 & 9,50 & 0,000 & $-2,500$ \\
\hline
\end{tabular}

Berdasarkan Tabel 3, dijelaskan bahwa terdapat perbedaan peningkatan body image pada hasil uji Mann Whitneyyang dilakukan setelah pemberian intervensi pada kelompok eksperimen dan kontrol. Terdapat perbedaan rata-rata antara kelompok kontrol $(X=3,50)$ dan kelompok eksperimen $(X=9,50)$. Skor yang didapatkan 
adalah $\mathrm{Z}=-2,892$ dan $\mathrm{p}=0,004 \quad(\mathrm{p}<0,05)$ maka dapat dikatakan bahwa terdapat perbedaan rerata body image yang signifikan pada kelompok eksperimen setelah diberikan intervensi. Dengan demikian, dapat disimpulkan bahwa hipotesis penelitian yang berbunyi acceptance and commitment therapy (ACT) mampu membangun body image positif pada pasien kanker payudara, diterima.

Berikut adalah perolehan skor prates dan pascates menggunakan body image scale (BIS) pada kelompok eksperimen.

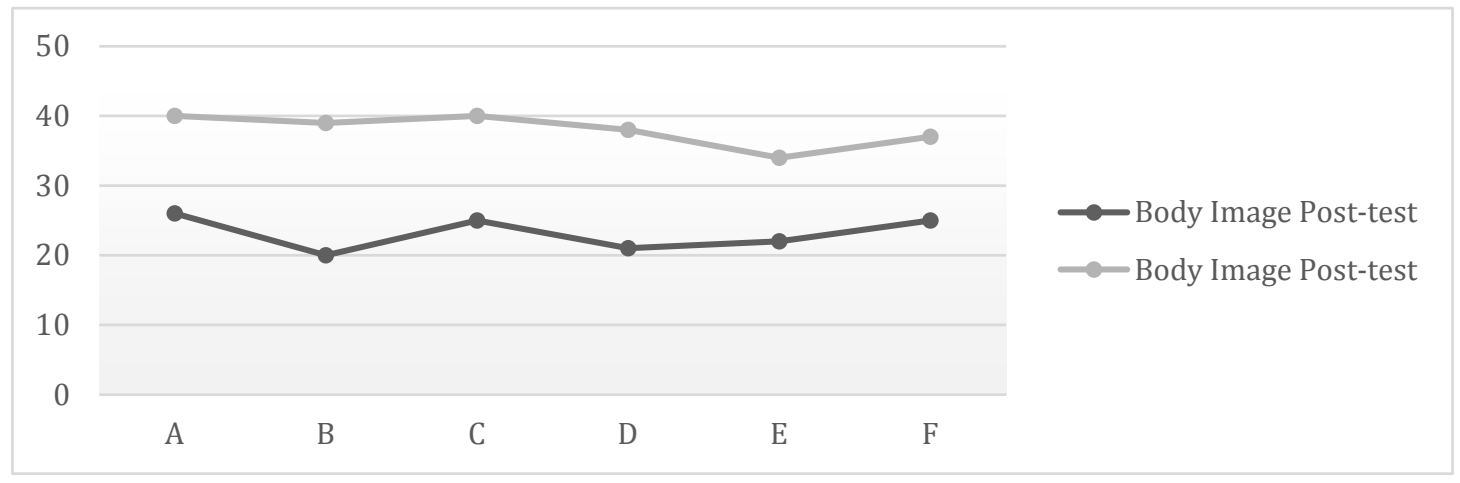

Gambar 2. Grafik Perbedaan Skor Body Image pada Sebelum dan Setelah Intervensi

Gambar 2 di atas menunjukkan bahwa terdapat peningkatan skor body image pada setiap subjek. Hal ini mengindikasikan adanya perubahan yang dialami subjek setelah diberi intervensi menggunakan ACT. Hasil evaluasi pada intervensi yang diberikan memberikan hasil bahwa ratarata subjek kelompok eksperimen mampu menerima perubahan penampilan yang diakibatkan dari perawatan kanker, mampu berinteraksi kembali dengan lingkungan, dan lebih menikmati kehidupannya, seperti berkurangnya mengeluh, menangis, menyalahkan diri sendiri atau Tuhan, dan melakukan aktivitas harian yang menyenangkan misalnya merawat bunga.

\section{Pembahasan}

Hasil penelitian menunjukkan bahwa ACT mampu membangun body image positif pada pasien kanker payudara. Berdasarkan wawancara dan pengisian BIS, diperoleh gambaran bahwa subjek merasa mendapat dukungan dan mulai mengurangi penilaian diri menggunakan standar orang lain sehingga mampu mengembangkan kesadaran dan memahami diri lebih baik dari sebelumnya. Hal ini terlihat juga dari perilaku yang ditunjukkan subjek yang mulai berkurang dalam mengurung diri, menangis, mengeluh dan sedih. Terdapat pula perbedaan skor BIS prates dan pascates pada kelompok eksperimen, membuktikan bahwa intervensi yang dilakukan mampu membangun body image positif pada pasien kanker payudara.

Perubahan yang dialami pasien kanker payudara dimulai dari perubahan dan penurunan fungsi fisik serta perubahan psikososial. Kondisi ini berdampak pada berkembangnya penilaian yang buruk pada diri dan tidak mampu menerima dirinya dengan baik. Mereka mengalami kesedihan yang signifikan, mengurung diri, menarik diri, merasa tidak berdaya, tidak memiliki harapan hidup, ketakutan akan kematian dan kecemasan yang berlebihan. Menurut 
Al-Azri et al., (2014) itu merupakan reaksi umum pasien kanker karena kanker merupakan penyakit yang disertai dengan nyeri kronis. Nyeri ini dirasakan secara terus menerus dan memicu beberapa reaksi buruk pada sebagian besar wanita.

Proses intervensi dilakukan secara individual pada seluruh subjek penelitian dengan melakukan diskusi sesuai dengan prinsip ACT. Proses intervensi ini mengutamakan proses penerimaan dengan latihan mengontrol dan memahami pikiran atau difusi kognitif. Mengontrol pikiran yang disesuaikan dengan nilai-nilai dan dihubungkan dengan kejadian saat ini. Hal ini dilakukan untuk membantu subjek mengendalikan pikirannya terkait penilaian dan persepsi tubuhnya berdasarkan standar orang lain, agar mampu tampil percaya diri serta menerima kondisinya sebagai pasien kanker payudara. Setelah mampu mengendalikan pikiran, subjek diberikan latihan metafora untuk membantu meningkatkan kesadaran akan kondisi yang dialami saat ini. Pemberian cerita pendek pada proses latihan dan melibatkan subjek di dalam cerita tersebut dapat mempengaruhi emosi dan kognisi. Perubahan pemahaman subjek mengenai konsep cantik yang tidak hanya dinilai dari kesempurnaan fisik berdampak pada penerimaan diri pada kondisi tubuh yang dimiliki. Proses penerimaan diri ini kemudian berpengaruh pada kepercayaan diri subjek. Berdasarkan hasil observasi peneliti, penerimaan dan kepercayaan yang tumbuh ini berhubungan dengan berkurangnya penilaian negatif pada tubuhnya. Selain itu, perubahan emosi terlihat dari setiap sesinya, di mana subjek mulai tenang dan berkurang mengeluhkan permasalahan bentuk fisiknya. Perubahanperubahan yang dialami subjek ini menunjukkan bahwa ACT mampu membantu pasien kanker payudara dalam menerima kondisi dirinya.
Melalui ACT, pasien kanker payudara juga mampu membangun body image positif sehingga mengurangi penilaian dan tidak lagi mempersepsi diri sebagai wanita tidak sempurna. Hasil penelitian ini selaras dengan penelitian yang telah dilakukan bahwa ACT mampu meningkatkan penerimaan terhadap body image dan menurunkan tingkat kekhawatiran terhadap penampilan secara berlebihan. Penelitianpenelitian tersebut menjelaskan bahwa penerimaan terhadap body image ditandai dengan meningkatnya kemampuan individu untuk kontak secara langsung dengan peristiwa saat ini dan mampu menentukan tindakan bertahan dengan ketidaknyamanan atau mengubah perilaku sesuai dengan tujuan dan nilai-nilai (Givehki et al., 2018; Griffiths, Williamson, Zucchelli, Paraskeva, \& Moss, 2018). Hal ini juga didukung penelitian Maryam (2019) yang menyatakan bahwa body image positif berhubungan secara signifikan terhadap penerimaan diri individu.

Individu dengan penerimaan diri yang baik berdampak pula pada persepsi body image positif pada pasien kanker. Penerimaan diri yang tinggi menjadikan individu memiliki sikap positif terhadap diri, mengakui dan menerima beberapa kondisi diri baik ataupun buruk dan menilai positif mengenai kehidupan masa lalu (Hernandez, 2014). Sebaliknya, individu yang memiliki penerimaan diri yang rendah cenderung kurang mampu bersikap positif dan menyalahkan diri akibat keterbatasan yang dimiliki atau kesalahan yang dilakukan (Vasile, 2016). Meningkatnya penerimaan pada pasien kanker payudara dapat dilihat dari perilaku berobat yang baik, berkurangnya perasaan tidak berdaya pada kondisi yang dihadapi, mampu menerima kondisi baik ataupun buruk, mampu berinteraksi dengan lingkungan dan berkurangnya penilaian negatif mengenai penampilannya. 
Faktor lain keberhasilan intervensi pada penelitian ini adalah dukungan keluarga. Dukungan keluarga merupakan salah satu faktor penting pada pasien kanker payudara, berdasarkan hasil riset terdahulu menunjukkan bahwa dukungan keluarga yang lebih tinggi berkaitan dengan risiko depresi yang lebih rendah. Sebuah studi longitudinal yang meneliti pasien selama 23 tahun juga melaporkan bahwa dukungan keluarga yang tinggi berkaitan dengan menurunnya tingkat depresi (Kamen, Cosgrove, Mckellar, Cronkite, \& Moos, 2011). Dukungan dari pasangan merupakan dukungan yang sangat penting. Penelitian $\mathrm{Su}$ et al., (2017) melaporkan bahwa dukungan yang besar dari pasangan berkaitan dengan tingkat depresi yang lebih rendah pada pasien kanker payudara.

Peningkatan pemahaman dan pengetahuan subjek mengenai penyakit yang dideritanya merupakan salah satu faktor pendukung keberhasilan intervensi. Mengetahui dan memahami kondisi saat ini berakibat pada perubahan pemahaman dan pemikiran mengenai kanker payudara (Naughton \& Weaver, 2014). Hal ini disampaikan oleh subjek bahwa memahami kondisi saat ini akan berdampak pada menurunnya penilaian terhadap penampilan fisik baik yang mengalami kecacatan ataupun penurunan fungsi serta mampu belajar menerima kondisi dirinya saat ini.

\section{SIMPULAN DAN SARAN}

Penelitian ini menunjukkan bahwa ACT memiliki pengaruh terhadap body image pada pasien kanker payudara.
Artinya, ACT mampu membangun body image positif pada pasien kanker payudara dan memberikan pemahaman mengenai kondisi diri yang lebih baik dari sebelumnya pada kelompok eksperimen. Selain itu, penerimaan diri yang baik ditunjukkan dari perilaku berobat yang baik, berkurangnya rasa tidak berdaya akibat kondisi, mulai berinteraksi kembali, serta berkurangnya penilaian terhadap penampilan akibat masektomi.

Penelitian ini diharapkan memberikan manfaat pada bidang ilmu psikologi klinis untuk menangani pasien kanker yang memiliki permasalahan body image. Kelebihan ACT ialah mengajarkan individu untuk mengelola dan mengendalikan pemikirannya dalam menghadapi kanker, sehingga mampu menerima dirinya saat ini dan mengurangi persepsi negatif terhadap penampilan. ACT juga dapat digunakan untuk membantu mengelola emosi terhadap perubahan yang dialami.

Keterbatasan dalam penelitian ini adalah peneliti menggunakan pengembangan terapi yang cukup baru sehingga masih perlu dikaji ulang dan diterapkan pada subjek yang berbeda-beda untuk melihat efektivitas terapi ACT. Bagi peneliti selanjutnya dapat mengembangkan, mereplikasi dan mengaplikasikan kembali acceptance and commitment therapy (ACT) kepada subjek dengan karakteristik yang mirip ataupun berbeda, misalnya pada pasien penyakit kronis lain. Selain itu, peneliti memberikan saran kepada keluarga agar memberikan dukungan dan penguatan positif kepada pasien kanker payudara selama menjalani perawatan. 


\section{DAFTAR PUSTAKA}

Al-Azri, M., Al-Awisi, H., Al-Rasbi, S., ElShafie, K., Al-Hinai, M., Al-Habsi, H., \& Al-Moundhri, M. (2014). Psychosocial impact of breast cancer diagnosis among Omani women. Oman Medical Journal, 29(6), 437-444. https:// doi.org/10.5001/omj.2014.115.

Al-Azri, M. H., Al-Awisi, H., Al-Rasbi, S., \& AlMoundhri, M. (2013). Coping with a diagnosis of breast cancer among Omani women. Journal of Health Psychology, 19(7). https://doi.org/ 10.1177/1359105313479813.

Allen, K. L., Byrne, S. M., \& Crosby, R. D. (2015). Distinguishing between risk factors for bulimia nervosa, binge eating disorder, and purging disorder. Journal of Youth and Adolescence, 44(8), 1580-1591. https://doi.org/ 10.1007/s10964-014-0186-8.

Arch, J. J., \& Mitchell, J. L. (2016). An acceptance and commitment therapy ( ACT ) group intervention for cancer survivors experiencing anxiety at reentry. Psycho-Oncoloy, 25(5), 610615. https://doi.org/10.1002/ pon.3890.

Bailey, K. A., Gammage, K. L., Ingen, C. Van, \& Ditor, D. S. (2015). " It' s all about acceptance ": A qualitative study exploring a model of positive body image for people with spinal cord injury. Body Image, 15, 24-34. https://doi.org/10.1016/j.bodyim. 2015.04.010.

Bates, G. (2016). Intimacy, body image, and cancer. JAMA Oncology, 2(12), 1667. https://doi.org/10.1001/jamaoncol. 2016.1196.

Bernard, M.E., (2013). The strength of selfacceptance: Theory, practice and research. New York: Springer. DOI 10.1007/978-1-4614-6806-6.
Bohon, C., Stice, E., \& Burton, E. (2010). Mantenance factors for persistance of bilic pathology: A prospective natural history study. International Journal Eat Disorder, 42(2), 173-178. https://doi.org/10.1002/eat.20600.M aintenance.

Cash, T., \& Smolak, L. (2011). Body image: $A$ handbook of science, practice, and prevention, 2nd ed. (T. F. Cash \& L. Smolak, Eds.), Body image: A handbook of science, practice, and prevention, 2nd ed. New York, NY, US: Guilford Press.

Cederberg, J. T., \& Dahl, J. (2017). An acceptance-based intervention for children and adolescents with cancer experiencing acute pain a singlesubject study. Journal of Pain Research, 10, 2195-2203.

Chen, S.-Q., Liu, J.-E., Zhang, Z.-X., \& Li, Z. (2017). Self-acceptance and associated factors among Chinese women with breast cancer. Journal of Clinical Nursing, 26(11-12), 15161523. https://doi.org/10.1111/ jocn.13437.

Chen, W., Zheng, R., Baade, P. D., Zhang, S., \& Zeng, H. (2016). Cancer statistics in China , 2015. CA:A Cancer Journal for Clinicians, 66(2), 115-132. https://doi.org/10.3322/caac.21338.

Corder, G. W., \& Foreman, D. I. (2014). Nonparametric statistics: a step-bystep approach (Secon Edit). New Jersey: Willey. https://doi.org/ 10.1002/9781118165881.

Creswell, J. W. (2010). Research design: pendekatan kualitatif, kuantitatif, dan mixed. Yogjakarta: PT Pustaka Pelajar. 
Datta, A., Aditya, C., Chakraborty, A., \& Das, P. (2015). The potential utility of acceptance and commitment therapy(ACT) for reducing stress and improving wellbeing in cancer patients in Kolkata. JOurnal of Cancer Education, 31(4), 721-729. https://doi.org/10.1007/s13187015-0935-8.

Feros, D. L., Lane, L., Ciarrochi, J., \& Blackledge, J. T. (2011). Acceptance and commitment therapy ( ACT ) for improving the lives of cancer patients?: a preliminary study. Psycho-Oncoloy, 22(2). https://doi.org/10.1002/pon.2083.

Fischer, D. J., \& Fink, B. C. (2014). Clinical processes in behavioral couples therapy. Psychotherapy, 51(1), 11-14. https://doi.org/doi:10.1037/a00338 23.

Givehki, R., Afshar, H., Goli, F., Scheidt, C. E., Omidi, A., Sciences, M., \& Instructor, F. (2018). Effect of acceptance and commitment therapy on body image flexibility and body awareness in patients with psychosomatic disorders: a randomized clinical trial. Electronic Psysician, 10(7), 70087016.

Griffiths, C., Williamson, H., Zucchelli, F., Paraskeva, N., \& Moss, T. (2018). A Systematic review of the effectiveness of acceptance and commitment therapy (ACT) for body image dissatisfaction and weight self-stigma in adults. Journal of Contemporary Psychotherapy.

https://doi.org/10.1007/s10879018-9384-0.

Han, J., Grothuesmann, D., Neises, M., Hille, U., \& Hillemanns, P. (2010). Quality of life and satisfaction after breast cancer operation. Gynecologic Oncology, 282, 75-82. https://doi.org/10.1007/ s00404-009-1302-y.
Han, J., Liu, J., Su, Y., \& Qiu, H. (2019). Effect of a group-based acceptance and commitment therapy (ACT) intervention on illness cognition in breast cancer patients. Journal of Contextual Behavior Science, 14(March), 73-81. https://doi.org/ 10.1016/j.jcbs.2019.09.003.

Hayes, S. C., Strosahl, K. D., \& Wilson, K. G. (2012). Acceptance and commitment therapy: The process and practice of mindful change, 2nd ed. Guilford Press. New York, NY, US: Guilford Press.

Hernandez, Pam Alfrey, "The right reflection: Improving women's selfacceptance" (2014). Master of Applied Positive Psychology (MAPP) Capstone Projects. 56. http://repository. upenn.edu/mapp_capstone/56

Hulbert, W. N. J., Storey, L., \& Wilson, K. G. (2015). Psychological interventions for patients with cancer: psychological flexibility and the potential utility of Acceptance and Commitment Therapy. European Journal of Cancer Care, 24(1), 15-27. https://doi.org/ 10.1111/ecc.12223.

Hopwood P, Fletcher I, Lee A, Al Ghazal S. A body image scale for use with cancer patients. Eur $J \quad$ Cancer. 2001;37(2):189-197. doi:10.1016/ s0959-8049(00)00353-1

Ízci, F. Ílgün, A.S., Findikli, E., \& Özmen, V. (2016). Psychiatric symptoms and psychosocial problems in patients with breast cancer. LBreast Health. 12(3): 94-101. Doi: 10.5152/ tjbh.2016.3041.

Jansen, A., Voorwinde, V., Hoebink, Y., Rekkers, M., Martijn, C., \& Mulkens, S. (2016). Mirror exposure to increase body satisfaction: Should we guide the focus of attention towards positively or negatively evaluated body parts? Journal of Behavior Therapy and Experimental Psychiatry, 50, 90-96. https://doi.org/10.1016/j.jbtep.2015. 06.002 . 
Kamen, C., Cosgrove, V., Mckellar, J., Cronkite, R., \& Moos, R. (2011). Family support and depressive symptoms: A 23-year follow-up. Journal of Clinical Psychology, 67(3), 215-223. https://doi.org/10.1002/jclp.20765.

Kangas, M., Mcdonald, S., Williams, J. R., \& Smee, R. I. (2015). Acceptance and commitment therapy program for distressed adults with a primary brain tumor: A case series study. Supportive Care in Cancer, 23(10), 2855-2859. https://doi.org/10.1007/s00520015-2804-8.

Karekla, M., \& Constantinou, M. (2010). Religious coping and cancer: Proposing an acceptance and commitment therapy approach. Cognitive and behavioral practice, 17(4), 371-381. https://doi.org/ 10.1016/j.cbpra.2009.08.003.

Kemkes.go.id. (2019). Hari kanker sedunia 2019.

https://www.kemkes.go.id/article/vi ew/19020100003/hari-kanker-

sedunia-2019.html diakses 15/05/2020.

Liu, J., Xu, C., \& Mahendran, R. (2017). Body image and emotional distress in newly diagnosed cancer patients?: The mediating role of dysfunctional attitudes and rumination. Body Image, 20, 58-64. https://doi.org/10.1016/ j.bodyim.2016.11.001.

Malik, A. A., \& Kiran, T. (2013). Psychological problems in breast cancer patients: A review. Chemotherapy, 2(114). https://doi.org/10.4172/21677700.1000115 .

Marco, J. H., Perpiñá, C., \& Botella, C. (2013). Effectiveness of cognitive behavioral therapy supported by virtual reality in the treatment of body image in eating disorders: One year follow-up. Psychiatry Research, 209(3), 619-625. https://doi.org/10.1016/j.psychres.2 013.02.023.
Maryam, S. (2019). Hubungan body image dengan penerimaan diri mahasiswa putri relationship between body image and self-acceptance of female students. Jurnal Aplikasi IPTEK Indonesia, 3(3), 129-136.

Montesinos, F., Luciano, C., Almería, U. De, \& Act, I. (2016). Acceptance of relapse fears in breast cancer patients: Effects of an act-based abridged intervention. Psicooncolodia, 13(1), 7-21. https://doi.org/10.5209/rev.

Naughton, M. J., \& Weaver, K. E. (2014). Physical and mental health among cancer survivors: considerations for long-term care and quality of life. North Carolina Medical Journal, 75(4), 283-286.

https://doi.org/10.18043/ncm.75.4.2 83.

Pearson, A. N., Follette, V. M., \& Hayes, S. C. (2012). A pilot study of acceptance and commitment therapy as a workshop intervention for body dissatisfaction and disordered eating attitudes. Cognitive and Behavioral Practice, 19(1), 181197. https://doi.org/10.1016/j.cbpra. $\underline{2011.03 .001}$

Najvani, B.D., Neshatdoost, H.T., Abedi, M.R., \& Mokarian, F. (2015). The effect of acceptance and commitment therapy on depression and psychological flexibility in women with breast cancer. Zahedan J Res Med Sci. 17(4):e965. DOI: http://sx.doi.org/10.17795/zjrms965

Pop, C. (2016). Self-esteem and body image perception in a sample of university students. Eurasian Journal of Education Researh, (64), 31-44.

Przezdziecki, A., Sherman, K. A., Baillie, A., Taylor, A., Foley, E., \& Stalgis-bilinski, K. (2013). My changed body: Breast cancer, body image, distress and selfcompassion. Psycho-Oncoloy, 22(8), 1872-1879. 
Rafiee, M., Sedrpoushan, N., \& Abedi. M. R. (2014). The effect of Acceptance and Commitment Therapy on reducing anxiety symptoms and body image dissatisfaction in obese women. Journal of Social Issues \& Humanities, 2 (1), 187-190.

Rosenberg, S. M., Tamimi, R. M., Gelber, S., Ruddy, K. J., Kereakoglow, S., Borges, V. F., ... Partridge, A. H. (2013). Body image in recently diagnosed young women with early breast cancer. Psyco-Oncology, 22, 1849-1855.

Rudiger, J. A., \& Winstead, B. A. (2013). Body talk and body-related co-rumination: Associations with body image, eating attitudes, and psychological adjustment. Body Image, 10(4), 462471. https://doi.org/10.1016/ j.bodyim.2013.07.010.

Secinti, E., Tometich, D. B., Johns, S. A., \& Mosher, C. E. (2019). The relationship between acceptance of cancer and distress: A meta-analytic review. Clinical Psychology Review, 71(May), 27-38. https://doi.org/10.1016/ j.cpr.2019.05.001.
Su, J.-A., Yeh, D. Y., Chang, C. C., Lai, C., Hu, P., \& Chin-hung, V. (2017). Depression and family support in breast cancer patients. Neuropsychiatric Disease and Treatment, 13, 2389-2396.

Tylka, T. L., \& Wood-Barcalow, N. L. (2015). What is and what is not positive body image? Conceptual foundations and construct definition. Body Image, 14, 118-129. https://doi.org/10.1016/ j.bodyim.2015.04.001.

Vasile, C. (2016). An evaluation of selfacceptance in adults. Procedia-Social and Behavioral Sciences, 78, 605-609. https://doi.org/10.1016/j.sbspro.201 3.04.360.

Wood-barcalow, N. L., Tylka, T. L., \& Augustus-horvath, C. L. (2010). “" But I Like My Body "': Positive body image characteristics and a holistic model for young-adult women. Body Image, 7(2), 106-116. https://doi.org/10.1016/ j.bodyim.2010.01.001. 